\title{
Technical note: Repeatability and reproducibility of curd yield and composition in a miniaturized coagulation model
}

\author{
G. Niero, ${ }^{1} \oplus$ A. Goi, ${ }^{1} \odot$ V. Vigolo, ${ }^{1} \oplus$ M. Saugo, ${ }^{1} \odot$ M. Franzoi, ${ }^{2} \oplus$ M. Cassandro, ${ }^{1} \oplus$ M. Penasa, ${ }^{1 *} \oplus$ \\ and M. De Marchi ${ }^{1}$ (D) \\ ${ }^{1}$ Department of Agronomy, Food, Natural resources, Animals and Environment, University of Padova, Viale dell'Università 16, 35020 Legnaro, \\ Italy \\ ${ }^{2}$ Breeders Association of Veneto Region (ARAV), Viale Leonardo Da Vinci 52, 36100 Vicenza, Italy
}

\section{ABSTRACT}

Miniaturized coagulation (MC) models have been proposed for the evaluation of curd yield (CY) in individual milk samples of different dairy species and breeds, and for the analysis of cheese microstructure and texture. It is still unclear if MC using less than $50 \mathrm{~mL}$ of milk is suitable to evaluate $\mathrm{CY}$ and chemical composition, and if preservative added to raw milk may interfere with MC process. Therefore, this study aimed at evaluating repeatability and reproducibility of CY, curd moisture, and fat and protein content on curd dry matter (DM) from MC trials using $40 \mathrm{~g}$ of milk. Miniaturized coagulations were performed by 3 different operators on 3 consecutive days, using raw milk (RM) and raw milk added with preservative (RMP). Repeatability of CY, calculated as relative standard deviation on 6 miniaturized curds obtained within a day by the same operator, was below $5 \%$ for MC carried out with both RM and RMP. The Horwitz ratio, which is the ratio between measured and expected reproducibility, highlighted good reproducibility for $\mathrm{CY}$ from RM and fair reproducibility for CY from RMP. The same ratio highlighted lower accuracies for curd moisture and fat and protein content on curd DM, especially for MC trials carried out with RMP. The z-test was performed to evaluate the similarity between curds manufactured with RM and RMP in terms of average yield and chemical composition; z-scores did not highlight significant differences between values obtained from MC carried out with RM and RMP. It can be concluded that preservative had negligible effects on MC, giving the opportunity to extend milk physical and chemical stability, to schedule laboratory trials on longer time span, and to broaden the sample size within a batch of analyses.

Received June 19, 2020.

Accepted August 13, 2020.

*Corresponding author: mauro.penasa@unipd.it
Key words: coagulation, cheese yield, milk, preservative, operator

\section{Technical Note}

Milk technological treatments are important within the dairy supply chain, providing added value to the original raw material. Regarding the dairy sector, milk coagulation and cheese manufacturing are among the major technological treatments. First, from a quantitative point of view, a large amount of milk is processed for cheese making, especially in Mediterranean countries where up to $70 \%$ of fluid milk is transformed in cheese (Pretto et al., 2013). Second, from a qualitative point of view, there are almost countless variants of cheese-making processes and types of cheese worldwide, which combine inestimable cultural and traditional values (MacDonald, 2013). Third, together with milk powders, cheese represents the easiest way to transport milk and to prolong milk shelf life, allowing easier trade across countries and continents. Lastly, cheese is a dairy product with great economic added value, providing sustainable incomes for farmers and for supply chain stakeholders. In this view, examples are provided by protected designation of origin cheeses (Pretto et al., 2013), as well as by global and local niche spread cheeses (Wilk, 2006). In this scenario, the scientific community has investigated milk coagulation properties and curd yield (CY) for decades, providing important advances in cheese-making practices and technologies. Milk clotting ability and CY have been widely described in relation to dairy species (Hussain et al., 2012) and breeds (Banks et al. 1986; Visentin et al., 2015), animal health and physiological status (Leitner et al., 2008), and farming systems and management (Niero et al., 2018). Also, different miniaturized coagulation (MC) models have been used to assess individual milk clotting ability and to develop novel receipts or production disciplines. Sturaro et al. (2015) used 10 L of bulk milk to assess the effect of different percentages of microparticulated 
whey protein on CY; Cipolat-Gotet et al. (2013) used $1.5 \mathrm{~L}$ of individual milk to investigate sources of variation of CY and nutrients recovery; Cologna et al. (2009) proposed a laboratory micromanufacturing method for assessing individual $\mathrm{CY}$ using $500 \mathrm{~mL}$ of milk; and Trancoso-Reyes et al. (2014) performed MC trials with $250 \mathrm{~mL}$ of milk to assess CY and evaluate microstructure and texture of miniature Chihuahua-type cheeses. So far, MC may be implemented by dairy enterprises as a supporting decision tool to test new cheese-making receipts or to decide which milk batches are better for cheese making and which for drinking milk. It is still unclear if $\mathrm{CY}$ and curd composition may be studied on even smaller MC scale models, and if these models are repeatable and reproducible. Moreover, to the authors' knowledge, there is no information on the effect of milk preservative on MC models. The use of preservative would make easier the application of $\mathrm{MC}$ on broader sample sets, due to extended physical and chemical stability of milk. The present work aimed to assess repeatability and reproducibility of CY and curd composition in a MC model using a very small amount of milk. Curd yield and composition were monitored in MC trials carried out with raw milk (RM) and raw milk added with preservative (RMP). A comparison between the 2 theses was performed to assess the effect of preservative on the studied traits.

Two samples of Simmental bulk RM (5.40 L each) were collected in November 2019 in the experimental farm L. Toniolo of the University of Padova (Legnaro, Italy) directly from the farm tank. One sample was immediately added with $0.5 \%$ (wt/wt) of preservative (Bronopol; 2-bromo-2-nitropropan-1,3-diol; Knoll Pharmaceuticals, Nottingham, UK). The RM and RMP samples were divided into 54 aliquots each (100 $\mathrm{mL}$ of milk/sample). All the resulting milk aliquots were transferred to the laboratory of the Breeders Association of Veneto Region (Padova, Italy) and stored at $4^{\circ} \mathrm{C}$ until analysis.

The first set of chemical analyses was performed in d 1, 3 h after milk sampling, on $18 \mathrm{RM}$ and $18 \mathrm{RMP}$ aliquots. Milk was warmed at $37^{\circ} \mathrm{C}$, gently mixed by inversion 10 times to promote fat and solids homogenization, and analyzed for fat, protein, casein, and lactose content and pH using a MilkoScan FT6000 (Foss, Hillerød, Denmark). After chemical analyses, milk aliquots were transferred to the laboratory of the Department of Agronomy, Food, Natural resources, Animals and Environment at the University of Padova (Legnaro, Italy). Milk aliquots were managed by 3 operators; each operator handled $6 \mathrm{MC}$ trials using RM and $6 \mathrm{MC}$ trials using RMP. Miniaturized coagulations were performed according to the following steps: (1) milk was gently mixed by inversion 10 times to promote solids homogenization; (2) $40 \mathrm{~g}$ of milk were poured into 50-mL disposable plastic tubes, and the exact milk weight was recorded; (3) milk was preheated in a water bath at $37^{\circ} \mathrm{C}$ for $1 \mathrm{~h}$ and added with $200 \mu \mathrm{L}$ of calf rennet (Naturen Plus 215, CHR Hansen, Hoersholom, Denmark) solution at a nominal concentration of 10.25 international milk clotting units/mL (McMahon and Brown, 1982); (4) the mixture was gently inverted 5 times and incubated in a water bath at $37^{\circ} \mathrm{C}$ for $30 \mathrm{~min}$; (5) the curd was cut 10 times using a stainless steel spatula and again incubated in a water bath at $37^{\circ} \mathrm{C}$ for $30 \mathrm{~min}$; (6) samples were centrifuged for $15 \mathrm{~min}$ at $2,700 \times g$ at room temperature; (7) after centrifugation whey was carefully discarded by inversion, and remaining whey was discarded using a pipette; (8) curd weight was recorded. Immediately after each single MC process, curd moisture, DM, fat, and protein content were determined through near-infrared spectroscopy using Foss DS2500 (Foss, Hillerød, Denmark). The same experimental design, including chemical analyses of RM and RMP aliquots, MC trials, and chemical analyses of curds, was repeated for d 2 and 3. Curd yield, fat on curd DM (fat DM), and protein on curd DM (protein DM) were calculated as:

$$
\begin{gathered}
\text { CY, } \%=\frac{\text { Curd weight, } \mathrm{g}}{\text { Milk weight, } \mathrm{g}} \times 100 ; \\
\text { Fat DM, } \%=\frac{\text { Curd fat, } \%}{\text { Curd DM, } \%} \times 100 ; \text { and } \\
\text { Protein DM, } \%=\frac{\text { Curd protein, } \%}{\text { Curd DM, } \%} \times 100 .
\end{gathered}
$$

Repeatability was measured as the relative standard deviation (RSD) calculated on CY, moisture, fat DM, and protein DM of 6 curds, obtained by the same operator within the same day. Day-related reproducibility was assessed as the relative standard deviation $\left(\mathbf{R S D}_{\mathrm{D}}\right)$ calculated on $\mathrm{CY}$, moisture, fat $\mathrm{DM}$, and protein $\mathrm{DM}$ of 18 curds, obtained by the same operator across d 1 , 2 , and 3. Similarly, operator-related reproducibility was evaluated as the relative standard deviation $\left(\mathbf{R S D} \mathbf{D}_{\mathbf{O}}\right)$ calculated on $\mathrm{CY}$, moisture, fat $\mathrm{DM}$, and protein $\mathrm{DM}$ of 18 curds, obtained by operators 1,2 , and 3 within the same day (Niero et al., 2019). Finally, the whole reproducibility was estimated as the relative standard deviation $\left(\mathbf{R S D}_{\mathrm{W}}\right)$ calculated on $\mathrm{CY}$, moisture, fat DM, and protein DM of 54 curds, obtained by 3 different operators in 3 different days of analyses (Landon et al., 2017). Horwitz ratio (HorRat) was used as comparison between measured $\mathrm{RSD}_{\mathrm{D}}, \mathrm{RSD}_{\mathrm{O}}$, and $\mathrm{RSD}_{\mathrm{W}}$ 
Table 1. Descriptive statistics for chemical composition of milk aliquots used for miniaturized coagulation trials ${ }^{1}$

\begin{tabular}{|c|c|c|c|c|c|c|c|c|c|c|}
\hline Trait & \multicolumn{5}{|c|}{$\mathrm{RM}(\mathrm{n}=54)$} & \multicolumn{5}{|c|}{$\mathrm{RMP}(\mathrm{n}=54)$} \\
\hline Fat, $\%$ & 3.78 & 0.12 & 3.69 & 4.00 & 3.11 & 3.74 & 0.05 & 3.67 & 3.86 & 1.44 \\
\hline Casein, \% & 2.64 & 0.01 & 2.62 & 2.64 & 0.24 & 2.64 & 0.01 & 2.62 & 2.65 & 0.35 \\
\hline Lactose, \% & 4.91 & 0.01 & 4.89 & 4.92 & 0.16 & 4.90 & 0.01 & 4.88 & 4.92 & 0.28 \\
\hline $\mathrm{pH}$ & 6.65 & 0.01 & 6.63 & 6.66 & 0.18 & 6.65 & 0.01 & 6.63 & 6.66 & 0.12 \\
\hline
\end{tabular}

${ }^{1} \mathrm{RM}=$ raw milk; $\mathrm{RMP}=$ raw milk with preservative.

and expected reproducibility. Day, operator, and whole HorRat $_{\left(\text {HorRat }_{\mathrm{D}}, \text { HorRat }_{\mathrm{O}} \text {, and HorRat }\right.}^{\mathrm{W}}$, respectively) were calculated as:

$$
\begin{gathered}
\text { HorRat }_{\mathrm{D}}=\frac{\operatorname{RSD}_{\mathrm{D}}}{2^{\left[1-0.5 \times \log \left(\frac{\mu}{100}\right)\right]},} \\
\text { HorRat }_{\mathrm{O}}=\frac{\mathrm{RSD}_{\mathrm{O}}}{2^{\left[1-0.5 \times \log \left(\frac{\mu}{100}\right)\right]}}, \text { and } \\
\text { HorRat }_{\mathrm{W}}=\frac{\operatorname{RSD}_{\mathrm{W}}}{2^{\left[1-0.5 \times \log \left(\frac{\mu}{100}\right)\right]}},
\end{gathered}
$$

where $\mu$ is the average CY, moisture, fat DM, or protein DM. According to Horwitz and Albert (2006), the reproducibility of the method is good when HorRat $\leq 1$, fair when $1<$ HorRat $\leq 2$, and low when HorRat $>2$. To evaluate the similarity between curds manufactured with RM and RMP, z-score (z) was calculated as:

$$
\mathrm{z}=\frac{m-\mathrm{VAL}_{\mathrm{REF}}}{\mathrm{SD}}
$$

where $m$ is the average $\mathrm{CY}$, moisture, fat $\mathrm{DM}$, or protein DM calculated on curds manufactured with RMP; and $\mathrm{VAL}_{\mathrm{REF}}$ and $\mathrm{SD}$ are the median and standard deviation, respectively, of $\mathrm{CY}$, moisture, fat $\mathrm{DM}$, or protein DM calculated on curds manufactured with RM. According to Thompson et al. (2006), the result from the 2 experimental conditions may be considered equal when $|z| \leq 2$, similar when $2<|z| \leq 3$, and different when $|z|>3$.

Descriptive statistics for chemical composition of RM and RMP used for MC trials are reported in Table 1. Fat content averaged 3.78 and $3.74 \%$ in RM and RMP, respectively, and protein and casein content averaged 3.35 and $2.64 \%$, both in RM and RMP. Milk solids content was slightly lower than average values reported by the Italian Simmental Association (ANAPRI, 2019). The relatively low SD and coefficient of variation $(\mathbf{C V}$; Table 1) are an important condition to achieve good repeatability and reproducibility of MC trials in terms of CY and composition. The CV for fat content (3.11 and $1.44 \%$ for RM and RMP, respectively) are numerically greater compared with those obtained for other milk constituents. This may be due to a physiological aggregation of fat globules along the $3 \mathrm{~d}$ of analysis and may partially justify the observed variability in terms of reproducibility and repeatability coefficients. Still, the CV can be considered low and thus acceptable, and average fat content obtained for RM and RMP samples were close in absolute value.

Repeatability for CY, calculated as RSD within day and operator, ranged from 0.43 to $1.55 \%$ and from 0.34 to $4.25 \%$ in MC trials carried out with RM and RMP, respectively (Table 2). Such results imply a good agreement for yields obtained from curds manufactured in the same day by the same operator. Repeatability values observed in the present study are comparable with those reported by other authors for different analytical applications and techniques, such as the quantification of milk iodine through inductively coupled plasma mass spectrometry (Niero et al., 2019) or the quantification of milk fatty acids through gas chromatography (Dias et al., 2008). Reproducibility, expressed as $\mathrm{RSD}_{\mathrm{D}}$ and $\mathrm{RSD}_{\mathrm{O}}$, showed a general worsening compared with the repeatability; this was somewhat expected because reproducibility was defined and calculated including days and operators as further sources of variation. This is also in agreement with previous authors who reported a worsening in the accuracy calculated between different days of analyses, compared with the accuracy calculated within a single day (Niero et al., 2017). Operatorrelated reproducibility was lower than the day-related reproducibility, suggesting that the effect of operator had major effect on the variability of CY. On one hand, it is likely that the tiny variation in terms of physical and chemical composition that might have occurred in milk across the $3 \mathrm{~d}$ of analyses affected $\mathrm{MC}$ to a 
Table 2. Repeatability (\%) within day and operator, day-related reproducibility ( $\left.\mathrm{RSD}_{\mathrm{D}}, \%\right)$, and Horwitz Ratio (HorRat $)$, and operator-related reproducibility $\left(\mathrm{RSD}_{\mathrm{O}}, \%\right)$ and Horwitz Ratio $\left(\right.$ HorRat $\left._{\mathrm{O}}\right)$ for curd yield

\begin{tabular}{|c|c|c|c|c|c|c|c|c|c|c|}
\hline \multirow[b]{2}{*}{ Trait } & \multicolumn{5}{|c|}{ Curds from RM $(\mathrm{n}=54)$} & \multicolumn{5}{|c|}{ Curds from RMP $(\mathrm{n}=54)$} \\
\hline & d 1 & $\mathrm{~d} 2$ & d 3 & $\mathrm{RSD}_{\mathrm{D}}$ & HorRat $_{\mathrm{D}}$ & d 1 & $\mathrm{~d} 2$ & d 3 & $\mathrm{RSD}_{\mathrm{D}}$ & HorRat $_{\mathrm{D}}$ \\
\hline Operator 1 & 0.99 & 0.56 & 1.55 & 1.06 & 0.41 & 0.84 & 0.47 & 4.25 & 3.11 & 1.20 \\
\hline Operator 2 & 0.43 & 1.28 & 0.86 & 1.23 & 0.48 & 0.80 & 1.18 & 0.34 & 1.00 & 0.39 \\
\hline Operator 3 & 0.90 & 0.84 & 0.66 & 1.62 & 0.63 & 1.63 & 2.16 & 0.78 & 1.58 & 0.61 \\
\hline $\mathrm{RSD}_{\mathrm{O}}$ & 1.48 & 1.99 & 1.71 & - & - & 2.25 & 2.68 & 4.80 & - & - \\
\hline
\end{tabular}

${ }^{1} \mathrm{RM}=$ raw milk; $\mathrm{RMP}=$ raw milk with preservative.

minor extent compared with the effect of 3 operators with different laboratory skills and dexterity. On the other hand, and from a practical point of view, the reproducibility of CY may be maximized when $\mathrm{MC}$ is carried out by the same operator across days and may be hampered when MC is performed by multiple operators within a day. Overall, HorRat ${ }_{\mathrm{D}}$ and HorRat $_{\mathrm{O}}$ were always $<1$ for $\mathrm{CY}$ from RM, and always $<2$ for $\mathrm{CY}$ from RMP, highlighting good and fair reproducibility, respectively.

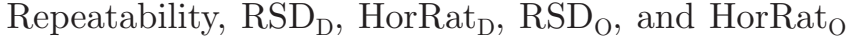
for chemical composition of curds manufactured with RM and RMP are in Table 3. Repeatability showed the best value for fat DM obtained in d 3 by operator 3 on curds manufactured with RM $(0.70 \%)$, and the worst value for protein DM obtained in d 3 by operator 1 on curds manufactured with RMP (6.78\%). The lowest and greatest $\mathrm{RSD}_{\mathrm{D}}$ were obtained by operator 1 for fat
DM on RM curds (1.15\%) and protein DM on RMP curds $(5.81 \%)$, respectively. On the other hand, $\mathrm{RSD}_{\mathrm{O}}$ ranged from $1.61 \%$ (fat DM in $\mathrm{d} 1$ on RM curds) to $5.41 \%$ (protein DM in d 3 on RMP curds). Ratios between measured and expected repeatability highlighted good performances only for fat DM of curds obtained

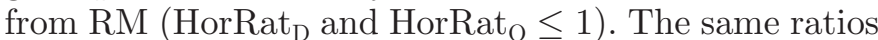
revealed fair to low reproducibility for the other traits, with broad variation depending on days and operators. In general, reproducibility for curd moisture, fat DM, and protein DM were worse compared with reproducibility of CY. It is likely that the accuracy of the method is greater in the case of direct measurements such as CY, and lower in the case of infrared predicted traits, probably due to the variability generated by the near-infrared instrument.

Descriptive statistics, RSD $\mathrm{W}$, HorRat ${ }_{\mathrm{W}}$, and z-scores for yield and chemical composition of curds manufac-

Table 3. Repeatability (\%) within day and operator, day-related reproducibility ( $\mathrm{RSD}_{\mathrm{D}}, \%$ ), and Horwitz Ratio (HorRat $\left.{ }_{\mathrm{D}}\right)$, and operator-related reproducibility $\left(\mathrm{RSD}_{\mathrm{O}}, \%\right)$ and Horwitz Ratio (HorRat ${ }_{\mathrm{O}}$ ) for curd chemical composition ${ }^{1}$

\begin{tabular}{|c|c|c|c|c|c|c|c|c|c|c|}
\hline Trait & \multicolumn{5}{|c|}{ Curds from RM $(\mathrm{n}=54)$} & \multicolumn{5}{|c|}{ Curds from RMP $(\mathrm{n}=54)$} \\
\hline Operator 2 & 2.92 & 4.08 & 3.77 & 3.63 & 1.69 & 3.92 & 1.70 & 1.48 & 4.74 & 2.20 \\
\hline Operator 3 & 3.03 & 1.58 & 1.20 & 2.30 & 1.07 & 1.99 & 1.36 & 3.15 & 2.18 & 1.02 \\
\hline $\mathrm{RSD}_{\mathrm{O}}$ & 2.56 & 4.09 & 3.26 & - & - & 4.64 & 3.20 & 4.11 & - & - \\
\hline \multicolumn{11}{|l|}{ Fat DM } \\
\hline Operator 1 & 0.82 & 1.31 & 0.96 & 1.15 & 0.52 & 1.84 & 0.71 & 3.68 & 3.71 & 1.70 \\
\hline Operator 2 & 1.21 & 2.73 & 1.86 & 2.25 & 0.99 & 3.40 & 3.20 & 2.27 & 3.34 & 1.52 \\
\hline Operator 3 & 2.50 & 1.20 & 0.70 & 2.13 & 0.97 & 3.78 & 1.97 & 2.90 & 2.83 & 1.29 \\
\hline $\mathrm{RSD}_{\mathrm{O}}$ & 1.61 & 2.20 & 1.89 & - & - & 3.30 & 2.48 & 4.61 & - & - \\
\hline HorRat $_{O}$ & 0.73 & 1.00 & 0.86 & - & - & 1.50 & 1.13 & 2.10 & - & - \\
\hline \multicolumn{11}{|l|}{ Protein DM } \\
\hline Operator 1 & 2.22 & 2.54 & 2.92 & 4.03 & 1.71 & 3.26 & 2.93 & 6.78 & 5.81 & 2.45 \\
\hline
\end{tabular}

${ }^{1} \mathrm{RM}=$ raw milk; RMP $=$ raw milk with preservative. 
tured with RM and RMP are in Table 4. Curd yield averaged 18.46 and $18.26 \%$ in MC trials with RM and RMP, respectively. Such results are about 2.5 percentage points lower than the average CY obtained by Sturaro et al. (2015) and 3.5 percentage points higher compared with the CY reported by Cipolat-Gotet et al. (2013), likely due to (1) differences in MC protocol adopted in the 2 studies, (2) specific aims and experimental design, and (3) number of milk samples processed for MC. Average fat DM and protein DM content were 53.18 and $33.25 \%$ in curds manufactured with RM and 53.62 and $32.71 \%$ in curds manufactured with RMP. Similar results were obtained by Sturaro et al. (2015) in curd obtained using MC and by TrancosoReyes et al. (2014) in fresh cheese obtained through a MC protocol that included a centrifugation step. In curds manufactured with $\mathrm{RM}$ the $\mathrm{RSD}_{\mathrm{W}}$ ranged from 1.83 to $3.64 \%$ for CY and moisture, respectively. Whole HorRat resembled the same variation, with the lowest value for CY (0.71) and the maximum for curd moisture (1.70). Overall, results suggest a good whole reproducibility for $\mathrm{CY}$ and fat $\mathrm{DM}$ content HorRat $_{\mathrm{W}}$ $<1$ ) and fair whole reproducibility for curd moisture and protein DM content $\left(1<\right.$ HorRat $\left._{W}<2\right)$. Whole HorRat showed a general worsening for curds manufactured with RMP, highlighting fair reproducibility for CY, moisture, and fat DM content $\left(1<\right.$ HorRat $\left._{W}<2\right)$, and low reproducibility for protein DM content (Hor$\operatorname{Rat}_{W}>2$ ). The z-scores were calculated to evaluate whether yield, moisture, fat DM, and protein DM in curds manufactured with RMP were in agreement with the same traits from curds manufactured with RM. For all traits z-scores were $<1$ in absolute value, suggesting that preservative added to RM had negligible effects on CY and composition (Thompson et al., 2006).

In conclusion, CY revealed satisfactory repeatability and reproducibility: the RSD within day and operator was always below $5 \%$; $\mathrm{RSD}_{\mathrm{D}}$ was lower than $\mathrm{RSD}_{\mathrm{O}}$, suggesting that operator had a major effect on the variability of CY; and HorRat ${ }_{D}$ and HorRat H $_{O}$ showed good reproducibility for $\mathrm{CY}$ from $\mathrm{RM}$ and fair reproducibility for CY from RMP. In terms of HorRat ${ }_{D}$ and HorRat the proposed MC method showed fair to low accuracy for curd moisture, fat DM, and protein DM. In general, it is likely that traits calculated through direct measurements (e.g., CY) are endowed with greater accuracies, whereas curd traits predicted through near-infrared spectroscopy (e.g., curd moisture, fat DM, and protein DM) are associated with lower repeatability and reproducibility. The z-scores calculated on average yield and chemical composition of curds manufactured with RM and RMP, highlighted that preservative added to RM had negligible effects on the studied traits.

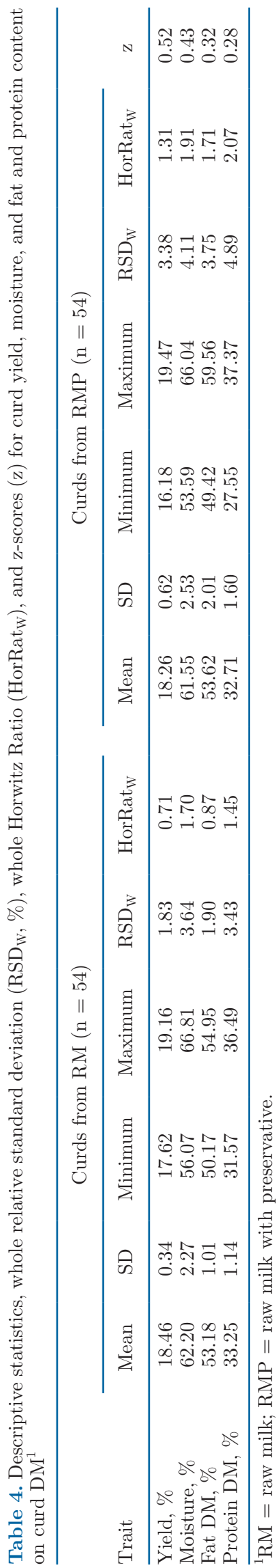

Journal of Dairy Science Vol. 103 No. 12, 2020 


\section{ACKNOWLEDGMENTS}

We gratefully acknowledge the Innovamilk project funded by AGER - Fondazione Cassa di Risparmio delle Province Lombarde (CARIPLO, Milano, Italy), the University of Padova (Legnaro, Italy), and the Italian Ministry of Education, University and Research (MIUR, Italy) for financing the acquisition of the Foss DS2500 instrument (Foss, Hillerod, Denmark) in the framework of the project CASA (Centro per l'Agricoltura, la Sostenibilità e gli Alimenti - CUP: C26C18000190001), through the program Dipartimenti di Eccellenza grant 2018-2022. The authors have not stated any conflicts of interest.

\section{REFERENCES}

ANAPRI (Associazione Nazionale Allevatori Pezzata Rossa Italiana). 2019. Average milk, fat and protein production on Simmental dairy cows. Accessed May 26, 2020. https://www.anapri.eu/it/ razza-pri/produttivita.html.

Banks, J. M., J. L. Clapperton, D. D. Muir, and A. K. Girdler. 1986. The influence of diet and breed of cow on the efficiency of conversion of milk constituents to curd in cheese manufacture. J. Sci. Food Agric. 37:461-468. https://doi.org/10.1002/jsfa.2740370505.

Cipolat-Gotet, C., A. Cecchinato, M. De Marchi, and G. Bittante. 2013. Factors affecting variation of different measures of cheese yield and milk nutrient recovery from an individual model cheesemanufacturing process. J. Dairy Sci. 96:7952-7965. https://doi .org/10.3168/jds.2012-6516.

Cologna, N., R. Dal Zotto, M. Penasa, L. Gallo, and G. Bittante. 2009. A laboratory micro-manufacturing method for assessing individual cheese yield. Ital. J. Anim. Sci. 8(Suppl. 2):393-395. https://doi .org/10.4081/ijas.2009.s2.393.

Dias, L. G., D. M. Correia, J. Sá-Morais, F. Sousa, J. Pires, and A. M. Peres. 2008. Raw bovine meat fatty acids profile as an origin discriminator. Food Chem. 109:840-847. https://doi.org/10.1016/ j.foodchem.2008.01.008.

Horwitz, W., and R. Albert. 2006. The Horwitz ratio (HorRat): A useful index of method performance with respect to precision. J. AOAC Int. 89:1095-1109. https://doi.org/10.1093/jaoac/89.4 .1095 .

Hussain, I., J. Yan, A. S. Grandison, and A. E. Bell. 2012. Effects of gelation temperature on mozzarella-type curd made from buffalo and cows' milk: 2. Curd yield, overall quality and casein fractions. Food Chem. 135:1404-1410. https://doi.org/10.1016/j.foodchem .2012.05.110.

Landon, G., C. Bouvier-Capely, A. Legrand, T. Sontag, G. Finance, M. Saint-Hilaire, F. Rebière, X. Millot, V. Renaud-Salis, and M. Agarande. 2017. Validation and comparison of two calibration methods for the measurement of stable iodine in the urinary matrix by ICP-MS: Standard addition vs. external calibration. Am. J. Anal. Chem. 8:245-263. https://doi.org/10.4236/ajac.2017.84019.

Leitner, G., N. Silanikove, and U. Merin. 2008. Estimate of milk and curd yield loss of sheep and goats with intrammamary infection and its relation to somatic cell count. Small Rumin. Res. 74:221225. https://doi.org/10.1016/j.smallrumres.2007.02.009.

MacDonald, K. I. 2013. The morality of cheese: A paradox of defensive localism in a transnational cultural economy. Geoforum 44:93-102. https://doi.org/10.1016/j.geoforum.2012.03.011.

McMahon, D. J., and R. J. Brown. 1982. Evaluation of Formagraph for comparing rennet solution. J. Dairy Sci. 65:1639-1642. https:/ /doi.org/10.3168/jds.S0022-0302(82)82390-4.

Niero, G., M. Franzoi, V. Vigolo, M. Penasa, M. Cassandro, C. Boselli, G. Giangolini, and M. De Marchi. 2019. Validation of a gold standard method for iodine quantification in raw and processed milk, and its variation in different dairy species. J. Dairy Sci. 102:4808-4815. https://doi.org/10.3168/jds.2018-15946.

Niero, G., M. Koczura, M. De Marchi, S. Currò, M. Kreuzer, G. Turille, and J. Berard. 2018. Are cheese-making properties of dual purpose cattle impaired by highland grazing? A case study using Aosta Red Pied cows. Ital. J. Anim. Sci. 17:827-834. https://doi .org/10.1080/1828051X.2018.1443289.

Niero, G., M. Penasa, S. Currò, A. Masi, A. R. Trentin, M. Cassandro, and M. De Marchi. 2017. Development and validation of a near infrared spectrophotometric method to determine total antioxidant activity of milk. Food Chem. 220:371-376. https://doi.org/10 .1016/j.foodchem.2016.10.024.

Pretto, D., M. De Marchi, M. Penasa, and M. Cassandro. 2013. Effect of milk composition and coagulation traits on Grana Padano cheese yield under field conditions. J. Dairy Res. 80:1-5. https:// doi.org/10.1017/S0022029912000453.

Sturaro, A., M. De Marchi, E. Zorzi, and M. Cassandro. 2015. Effect of microparticulated whey protein concentration and protein-tofat ratio on Caciotta cheese yield and composition. Int. Dairy J. 48:46-52. https://doi.org/10.1016/j.idairyj.2015.02.003.

Thompson, M., S. L. R. Ellison, and R. Wood. 2006. The International Harmonized Protocol for the proficiency testing of analytical chemistry laboratories (IUPAC Technical Report). Pure Appl. Chem. 78:145-196. https://doi.org/10.1351/pac200678010145.

Trancoso-Reyes, N., N. Gutiérrez-Méndez, D. R. Sepulveda, and L. R. Hernández-Ochoa. 2014. Assessing the yield, microstructure, and texture properties of miniature Chihuahua-type cheese manufactured with a phospholipase $\mathrm{A}_{1}$ and exopolysaccharide-producing bacteria. J. Dairy Sci. 97:598-608. https://doi.org/10.3168/jds .2013-6624.

Visentin, G., M. Penasa, P. Gottardo, G. Niero, M. Isaia, M. Cassandro, and M. De Marchi. 2015. Milk coagulation properties of cattle breeds reared in Alpine area. Poljoprivreda (Osijek) 21(1 sup):237-240. https://doi.org/10.18047/poljo.21.1.sup.56.

Wilk, R. 2006. Fast Food/Slow Food: The Cultural Economy of the Global Food System. Rowman Altamira, Lanham, MD.

\section{ORCIDS}

G. Niero $\odot$ https://orcid.org/0000-0002-6169-1162

A. Goi $\odot$ https://orcid.org/0000-0003-3341-9775

V. Vigolo ৫ https://orcid.org/0000-0001-6413-3257

M. Saugo ๑ https://orcid.org/0000-0002-9979-2153

M. Franzoi ๑ https://orcid.org/0000-0001-8701-5632

M. Cassandro ( https://orcid.org/0000-0002-8709-2870

M. Penasa @ https://orcid.org/0000-0001-9984-8738

M. De Marchi ๑ https://orcid.org/0000-0001-7814-2525 